Original article

\title{
Prevalence of Hepatitis $C$ virus and determination of its genotypes in subjects of Tehsil Daggar District Buner, KP, Pakistan
}

\author{
Zeeshan Qamar $^{\mathrm{a}}$, Faheem Anwar ${ }^{\mathrm{a}, \ldots \ldots *}$, Raiz Ahmad ${ }^{\mathrm{b}}$, Ihteshamul Haq ${ }^{\mathrm{a}}$, Mohsina haq ${ }^{\mathrm{c}, \mathrm{d}}$, \\ Arbab Muhammad Kashif Khan ${ }^{e}$, Rafiq Hussain ${ }^{\mathrm{f}}$, Abd ullah ${ }^{\mathrm{g}, * *}$, Zeeshan Shahzad ${ }^{\mathrm{a}}$, \\ Ibrar Ahmad a , Muhammad Salman Munir Malik ${ }^{\mathrm{h}}$, Muhammad Kamran khan ${ }^{\mathrm{a}}$, Jawad Khan ${ }^{\text {a, }}$ \\ ${ }^{a}$ Department of Biotechnology and Genetic Engineering, Hazara University, Mansehra, 21300, KP, Pakistan \\ ${ }^{\mathrm{b}}$ Department of Zoology, Govt Post Graduate College, Daggar, Buner, KP, Pakistan \\ c Pathology Department, Peshawar Medical College, Peshawar, Pakistan \\ ${ }^{\mathrm{d}}$ Riphah International University, Islamabad, Pakistan \\ e Prime Teaching Hospital, Warsak Road, Peshawar, KP, Pakistan \\ ${ }^{\mathrm{f}}$ Department of Biological Sciences, University of Lakki Marwat, KP, Pakistan \\ ${ }^{g}$ Department of Health and Biological Sciences, Abasyn University, Peshawar, Pakistan \\ h Department of Microbiology, Government College University, Faisalabad, Pakistan
}

\section{A R T I C L E I N F O}

\section{Keywords:}

$\mathrm{HCV}$

Buner

PCR

RNA virus

Genotyping

\begin{abstract}
A B S T R A C T
Background: Hepatitis $\mathrm{C}$ is a noteworthy public health issue around the globe, resulting in liver-related problems. The disease is caused Hepatitis $\mathrm{C}$ virus a positive sense RNA virus belongs to Flaviviridae family. Approximately $6 \%$ population of Pakistan is infected with HCV. Due to genetic variation, HCV is categorized into 7 genotypes and 67 subtypes.

Methodology: In this study total 1100 ICT positive samples were collected from December 2016 to May 2017 from Tehsil Dagger District Buner. RNA was extracted from ICT positive serum samples of 1100 patients and, were screened for HCV-RNA by using Reverse Transcriptase-Nested polymerase chain reaction (RT-nested PCR) and, then the positive samples were subjected for HCV genotyping. Statistical analysis was carried on SPSS version 10.0 .

Results: Out of 1100 ICT positive samples, HCV RNA was detected in 375 individuals, of which $14.9 \%$ were males and, $19.2 \%$ females. The frequency of HCV genotypes Untypable was 43.5\%), followed by 3a (29.6\%), 3 b was $9.6 \%$, 2a was $5.9 \%$, 1a was $5.3 \%, 1 \mathrm{~b}(4.0 \%)$ and, 2 b was $1.9 \%$ in these patients. Both genotypes untypable and 3a were the most prevalent genotypes in patients of all age groups and its prevalence was found high among patients with increasing age ( $>30$ years). The prevalence rate of HCV in age of $21-30$ years (30.1\%), of 31-40 years the percentage of positive cases are $24.85 \%$ and $11-20$ years of age group is (11.4\%). Furthermore, genotypes untypable, $3 \mathrm{a}$ and $3 \mathrm{~b}$ were found to be the most common genotypes in patients with history of barber shops, dental surgery, and receiving multiple injections.

Conclusion: The current study reveals HCV untypable variants as the most frequent genotypes in the HCV patients of district Buner KP, Pakistan, with most patients in the age group 21-30 years. HCV various isolates were associated with different routes of transmission. The predominant factors of HCV included shaving in barber shops and intra-venous drugs use. These findings may suggest anti-HCV therapy and monitoring HCV infections.
\end{abstract}

\section{Introduction}

Globally, the Hepatitis C virus (HCV) is the most common causative agent of chronic viral liver diseases. Currently, there has been an increase in the number of HCV cases around the world and it has emerged as one of the frequent causes of acute and chronic liver diseases. ${ }^{1} \mathrm{HCV}$ is

\footnotetext{
* Corresponding author.

$* *$ Corresponding author.

$* * *$ Corresponding author.

E-mail addresses: faheem_genetics@hu.edu.pk (F. Anwar), abdullah4sawkum.77@gmail.com (A. ullah), jawad_genetics@hu.edu.pk (J. Khan).
} 
a member of the viral family Flaviviridae that contains a $10 \mathrm{~kb}$ long positive sense single-stranded an enveloped RNA genome. ${ }^{2}$ The Mortality rate of HCV is very high around 350,000 people die every year after acquired HCV infection. ${ }^{3}$ According to WHO reports the morbidity of HCV infection has a high impact on public health, approximately 170 million individuals are infected with HCV infection worldwide. ${ }^{4}$ The epidemiology of hepatitis C virus (HCV) infections in the United States (US) has changed dramatically over the last decade, with notable increases in HCV incidence among young people aged approximately 15-29 years. ${ }^{5}$ The Middle East and North Africa (MENA) region is the most affected region by HCV infection, with approximately 15 million individuals chronically infected. ${ }^{4} \mathrm{HCV}$ infection mainly occurs through parental routes such as past blood transfusions intravenous drug abuse involving sharing of syringes, and the use of unsterilized medical or non-medical device. ${ }^{6}$ HCV causes acute hepatitis after $40-120$ days of incubation period following the initial infection. About $20-50 \%$ of acute hepatitis C to $80 \%$ will develop chronic HCV infection. If chronic HCV infection is not treated by antiviral therapy, HCV infection is maintained throughout the person's lifetime, and death from liver disease. ${ }^{7} \mathrm{HCV}$ has shown a high rate of genetic variability, this characteristic allowed the HCV strains to categorize into distinct groups known as genotypes, subtypes, isolates, and subspecies. The documented genetic diversity among HCV strains is $65.8 \%-68.7 \%$, nucleotide sequence identities of full-length sequences for type, subtypes isolates, and subspecies are, 76.9\%-80.1\%, 90.8\%-99\% respectively. ${ }^{8,9}$ There are six major genotypes reported so far with untypable and mixed genotypes. 1-6 has more than fifty subtypes, these genotypes have differed $31-34 \%$ based on nucleotide sequences while the subtypes are different $20-23 \%$ based on full-length genomic sequences. This widespread genetic variability, and mutation tendency has delayed vaccine availability. ${ }^{10} \mathrm{HCV}$ is highly endemic in the various regions of Pakistan, the exact prevalence rate of HCV infection is still unknown, different reports revealed that $4.8 \%$ of population is infected with HCV infection. ${ }^{11}$ Understanding HCV epidemiology in Pakistan is critical in developing and targeting cost-effective prevention and treatment intervention against $\mathrm{HCV}$, to meet the global target of HCV elimination. A Previous study reported that $13.7 \%$ of population is infected with HCV infection in district Buner. ${ }^{12}$ It is worthy to investigate HCV frequency and distribution of HCV genotypes in tehsil daggar district Buner, KP Pakistan, where detection and genotype determination is insignificant. Consequently, the present study was undertaken to analyze the distribution pattern of HCV genotypes as well as their prevalence and risk factors, and routes of transmission in chronic hepatitis C patients of Buner, Khyber Pakhtunkhwa (KP) in Pakistan.

\section{Method and material}

\subsection{Study area}

Buner is a District in the Malakand Division of Khyber Pakhtunkhwa province of Pakistan. Buner District lies between $34-9^{\circ}$ and $34-43^{\circ} \mathrm{N}$ latitude and $72-10^{\circ}$ and $72-47^{\circ} \mathrm{E}$ longitude. It is bounded on the North by District Swat, on the west by Malakand, on the South by district Mardan and the east by Indus River and Hazara division. According to 2017 census the total population of District Buner is 897,319. The average temperature of the region is $19-30{ }^{\circ} \mathrm{C}$ and $672-1198-\mathrm{mm}$ rainfall per annum.

\subsection{Sample collection}

In the current study 1100 ICT positive blood sample were collected from District headquarter hospital (DHQ) Daggar and some near private hospitals at District Buner, KP, Pakistan from the period of December 2016 to May 2017. About $5 \mathrm{~mL}$ venous blood sample was collected from each patient. All personal information about the patient's medical history was collected through consent forms such as age, gender, geographical region, and risk factors for HCV infection such as dialysis, blood transfusion, I.V drug abuse, tattoos, household contacts and health care employment with exposure to blood.

\subsection{Initially screening on immunochromatographic test (ICT)}

Initially, the collected samples were screened for HCV antibodies using ICT kit (Accurate Diagnostic, Canada), according to manufacturer instructions.

\subsection{RNA extraction}

Blood samples were centrifuged at $8000 \mathrm{rpm}$ for $10 \mathrm{~min}$ and Serum was collected and stored in small aliquots at $-20{ }^{\circ} \mathrm{C}$ for further processing. RNA was extracted from $100 \mu$ l serum by using Ana-gen RNA extraction kit (Ana-gen, USA) according to the manufacturer's instructions. Qualitative detection of serum HCV RNA was performed by Reverse transcription PCR. ${ }^{13}$

\subsection{HCV qualitative test}

For further reliability, HCV Qualitative test was performed. Samples were subjected firstly for the detection of HCV RNA qualitatively as previously described by Idrees $2008 .{ }^{13}$ For HCV RNA detection Reverse transcription PCR (RT-PCR) was done. For RNA extraction $100 \mu \mathrm{l}$ sample was taken using a Quigen RNA extraction kit as described by the kit protocol. Afterward, Nested PCR was conducted by using Taq DNA polymerase enzyme (Fermentas Technologies USA). The Volume of $20 \mu \mathrm{l}$ reaction mix Taq Pol was taken, and the products were examined by visualizing on $2 \%$ agarose gel. "UVITEC" gel documentation system was used for UV light.

\subsection{HCV quantitative test}

For the Quantification test, Smart Cycler II Real-time PCR (Cepheid, Sunnyvale, Calif. USA). Was used. HCV RNA quantification kits were applied (Sacace Biotechnologies, Italy). The Smart Cycler II system is a PCR system that uses TaqMan technology by which amplification and diagnosis were accomplished (Applied Biosystem, Foster City, Calif). In this method, fluorescent probes are used to examine the amplification of DNA after each replicating cycle. The detection limits of the used assay were $250 \times 108 \mathrm{IU} / \mathrm{mL}$ for lower and $5.0 \times 108 \mathrm{IU} / \mathrm{mL}$ for upper, respectively. Above the upper limit values, specimens were diluted 100 fold and retested. Obtained values were then multiplied by the dilution factors (IU per $\mathrm{mL}$ ).

\subsection{HCV genotyping}

HCV genotyping was performed using type-specific HCV genotyping procedure as previously described in detail. ${ }^{13}$ Shortly, $50 \mathrm{ng}$ was reverse transcribed to cDNA at using $100 \mathrm{U}$ of M-MLV RTEs. By first-round PCR amplification, 2 micro-liters of synthesized cDNA was used for PCR amplification of the 470-bp region from HCV $5^{\prime} \mathrm{NCR}$, as well as the core region. The products of the first round were put into nested PCR amplification second round. In a reaction volume of $10 \mu \mathrm{l}$, one with mix-I primers set and the other with mix-II primers set. Mix-I included specific genotype primers for $1 \mathrm{a}, 1 \mathrm{~b}, 1 \mathrm{c}, 3 \mathrm{a}, 3 \mathrm{c}$, and 4 genotypes, while mix-II included specific genotype primers for $2 \mathrm{a}, 2 \mathrm{c}, 3 \mathrm{~b}, 5 \mathrm{a}$, and $6 \mathrm{a}$ genotypes.

\subsection{Statistical analysis}

Given data was analyzed and the summary statistic was carried out by a statistical package, SPSS version 10.0. The information recorded and put into tabular form and variables results were given in the form of rates (\%), and frequency, number of patients, categorical variables, and 
Table 1

Analysis of Total Data Gender wisely out of 1100 cases.

\begin{tabular}{|c|c|c|c|c|c|c|}
\hline Gender of the Patients & Result Positive & Percentage & Result Negative & Percentage & Total & Percentage \\
\hline Male & 164 & $14.9 \%$ & 344 & $31.3 \%$ & 508 & $46.2 \%$ \\
\hline Female & 211 & $19.2 \%$ & 381 & $34.6 \%$ & 592 & $53.8 \%$ \\
\hline Sum & 375 & $34.1 \%$ & 725 & $65.9 \%$ & 1100 & 100 \\
\hline
\end{tabular}

Table 2

Analysis of Data out of 375 cases based on HCV Genotype detected.

\begin{tabular}{lll}
\hline HCV Genotype Detected & Subject Frequency & Percentage \\
\hline Untypable & & \\
Genotype 1a & 163 & $43.5 \%$ \\
Genotype 1b & 20 & $5.3 \%$ \\
Genotype 2a & 15 & $4.0 \%$ \\
Genotype 2b & 22 & $5.9 \%$ \\
Genotype 3a & 7 & $1.9 \%$ \\
Genotype 3b & 112 & $29.6 \%$ \\
Total Patients & 36 & $9.6 \%$ \\
\hline
\end{tabular}

quantitative measurement.

\section{Results}

Out of 1100 ICT positive samples, HCV RNA was detected in 375 individuals, of which $14.9 \%$ were males and, $19.2 \%$ females as shown in Table.No1. According to PCR detection (34.1\%) subjects were positive for HCV.

The qualitative PCR positive samples were subjected to genotyping assay out of 375 serum type-specific PCR fragments were seen in 212 serum samples whereas 163 samples were found with untypable genotypes as no genotype-specific band was seen in these samples. Out of the total 375 tested serum samples, 212 (56.53\%) were successfully genotyped whereas 163 (43.46\%) samples were found with untypable genotypes. Among typable genotypes, $1 \mathrm{a}$ accounted for $20(5.3 \%) 1 \mathrm{~b}$ for 15 (4.0\%), 2a for $22(5.9 \%), 2$ b for $7(1.9 \%)$, 3a for $112(29.6 \%)$ and genotype $3 \mathrm{~b}$ for $36(9.6 \%)$ patients were infected with HCV as shown in Table.No2 and Fig.No1.

Based on Marital along with gender status of patients, higher positivity was found in married females (15.09\%) as compared to unmarried (4.09\%) in Table No4. Although in married males' higher frequency was (11.54\%) as compared to unmarried (3.36\%), as shown in Table.No3.

According to academic qualification higher HCV prevalence was observed in uneducated $(20.63 \%)$ in comparison with educated individuals (13.45\%) as shown in Table No4. The results show continuous morbidity of HCV cases in general population of district Buner. The highest frequency of cases due to the lack of knowledge, awareness, and it can rightly be said that they are mostly from villages belonging to low socioeconomic group with high rate of illiteracy.

Based on age wise analysis a significant increase were seen in age group $21-30$ years (30.1\%), followed by $31-40$ years (G-4), $24.85 \%$, (G1), $1-10$ years $4 \%$ and $11-20$ years (G-2) $11.4 \%$ as shown in Table.No5.

Based on certain practices HCV infection and its genotypes prevalence are linked with certain professions and medical history of the subjects could be known routes of transmission. Genotype 3a and untypable genotype were found most prevalent genotypes in patients with history of shaving by barbers as compared to another HCV

\section{HCV Genotype Detected}
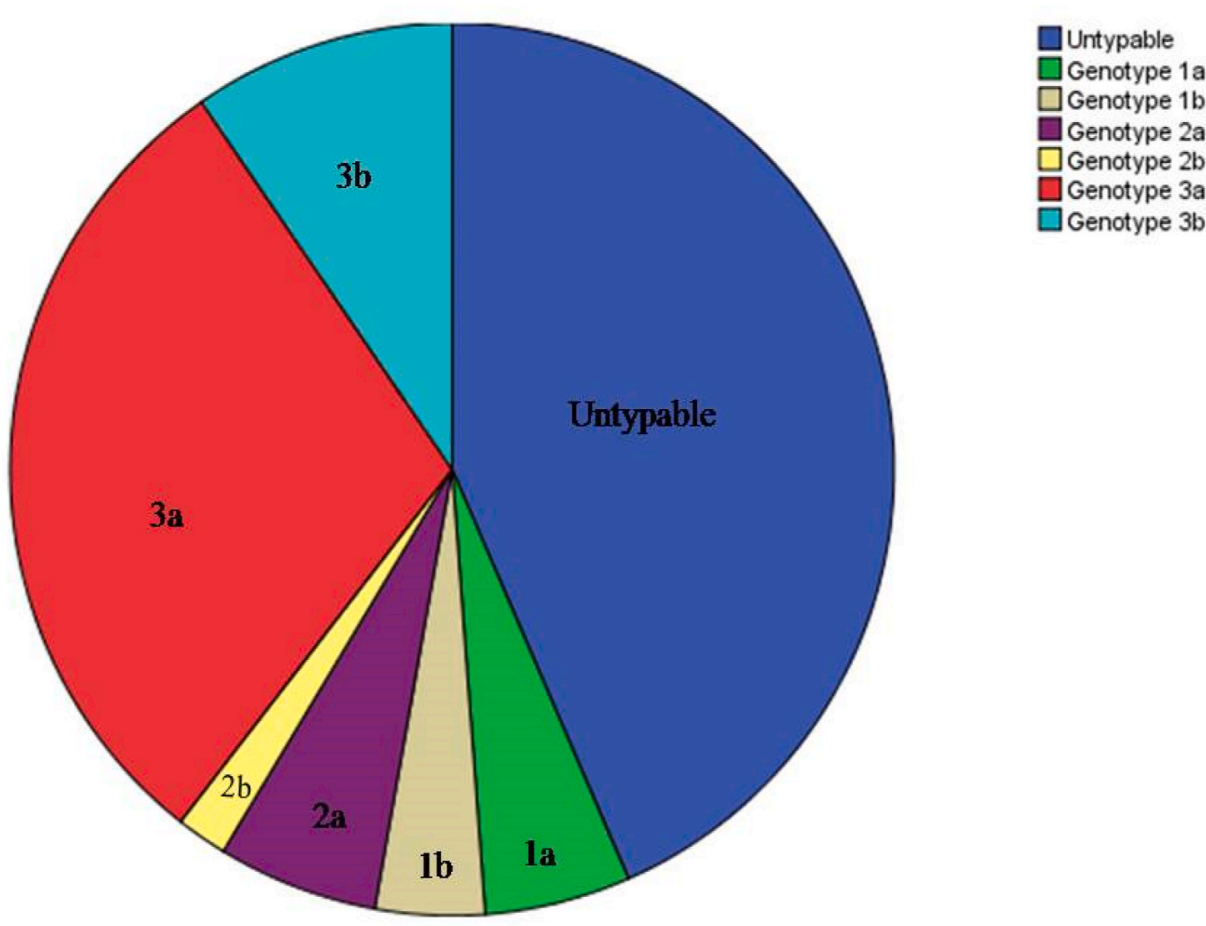

Fig. 1. Graphical representation of Genotype detected wise Analysis of Positive cases. 
Table 3

Marital status wise analysis of the total data out of 1100 cases.

\begin{tabular}{|c|c|c|c|c|c|c|}
\hline \multicolumn{7}{|c|}{ Marital status of the individual } \\
\hline \multicolumn{7}{|c|}{ Marital status wise analyses of the Positive Patients } \\
\hline Gender & Married & Percentage & Unmarried & Percentage & Total & Percentage \\
\hline Male & 127 & $11.54 \%$ & 37 & $11.54 \%$ & 164 & $14.90 \%$ \\
\hline Female & 166 & $15.09 \%$ & 45 & $15.09 \%$ & 211 & $19.18 \%$ \\
\hline Total & 293 & $26.63 \%$ & 82 & $26.63 \%$ & 375 & $34.09 \%$ \\
\hline \multicolumn{7}{|c|}{ Marital status wise analyses of the Negative Cases reported } \\
\hline Gender & Married & Percentage & Unmarried & Percentage & Total & Percentage \\
\hline Male & 254 & $23.09 \%$ & 90 & $8.18 \%$ & 344 & $31.27 \%$ \\
\hline Female & 320 & $29.09 \%$ & 61 & $5.54 \%$ & 381 & $34.63 \%$ \\
\hline Total & 574 & $52.18 \%$ & 151 & $13.72 \%$ & 725 & $65.90 \%$ \\
\hline
\end{tabular}

Table 4

Qualification wise analysis of total data out of 1100 cases.

\begin{tabular}{|c|c|c|c|c|c|c|}
\hline \multicolumn{7}{|c|}{ Gender of the Patient $\times$ Educational Qualification of the Gender } \\
\hline \multicolumn{7}{|c|}{ Qualification wise analyses of the Positive Patients } \\
\hline Gender & Educated & Percentage & Uneducated & Percentage & Total & Percentage \\
\hline Male & 97 & $8.81 \%$ & 67 & $6.09 \%$ & 164 & $14.90 \%$ \\
\hline Female & 51 & $4.6 \%$ & 160 & $14.54 \%$ & 211 & $19.18 \%$ \\
\hline Total & 148 & $13.45 \%$ & 227 & $20.63 \%$ & 375 & $34.09 \%$ \\
\hline \multicolumn{7}{|c|}{ Qualification wise analyses of the Negative Cases reported } \\
\hline Gender & Educated & Percentage & Uneducated & Percentage & Total & Percentage \\
\hline Male & 160 & $14.54 \%$ & 184 & $16.72 \%$ & 344 & $31.27 \%$ \\
\hline Female & 103 & $9.36 \%$ & 278 & $25.27 \%$ & 381 & $34.63 \%$ \\
\hline Total & 263 & $23.90 \%$ & 462 & $42 \%$ & 725 & $65.90 \%$ \\
\hline
\end{tabular}

Table 5

HCV Positive subjects age wise analysis of the data out of 375 cases.

\begin{tabular}{llllll}
\hline $\begin{array}{l}\text { Distribution of } \\
\text { Groups }\end{array}$ & $\begin{array}{l}\text { Age of positive } \\
\text { patients }\end{array}$ & Male & Female & Total & Percentage \\
\hline G-1 & $1-10$ & 8 & 7 & 15 & $4 \%$ \\
G-2 & $11-20$ & 22 & 21 & 43 & $11.4 \%$ \\
G-3 & $21-30$ & 45 & 68 & 113 & $30.1 \%$ \\
G-4 & $31-40$ & 41 & 52 & 93 & $24.8 \%$ \\
\hline
\end{tabular}

*The statistical analysis does not reveal a significant association $(p>0.05)$ between the genders.

genotype in Tehsil Daggar district Buner. Possible routes of transmission of HCV genotypes among the patients were recorded major risk factors for HCV transmission, barber shop (27.4\%), Heterosexuality (12.2\%), Traffic accident or puncture with other object contaminated with blood (11.7\%), Homosexuality (7.7\%), dental procedures $(5.86 \%)$, uses of unsterilized materials (4.2\%), Surgeries (3.2\%), Blood transfusion $(0.8 \%)$ is shown in Table 6.

\section{Discussion}

Approximately two million people dies annually due to liver disease, reports confirmed that 1 million is owing to viral hepatitis and hepatocellular carcinoma and remaining due to complications of liver cirrhosis. Liver cirrhosis is 11th most frequent fatal disease, and liver cancer with $3.5 \%$ mortality rate reported as 16th leading cause of death. ${ }^{14} \mathrm{HCV}$ is a blood borne virus which transmit from person to person via surgery, barbers' shops, dental surgery, injection drug use and occupational needle pricks. ${ }^{15-17}$ It is calculated that $6 \%$ of population of Pakistan is infected with HCV. ${ }^{18}$ Epidemiological reports that precisely present the frequency of HCV infection accompanied by geographic analysis of HCV genotypes are very critical. These studies can assist in more development in therapeutic and preventive approaches. ${ }^{19}$ In current study 1100 positive cases were examined for HCV-RNA of which 375 (34.1\%) individuals were observed in all age groups. Our study showed relationships between frequency of HCV genotypes and mode of transmission in gender and various age groups. Our results showed non-significant association between age and gender. In accordance to our finding the similar association was found by Ahmad

Table 6

Possible routes of transmission of HCV genotypes among the subjects.

\begin{tabular}{|c|c|c|c|c|c|c|c|c|c|}
\hline Possible routes of transmission & $1 \mathrm{a}$ & $1 \mathrm{~b}$ & $2 \mathrm{a}$ & $2 \mathrm{~b}$ & $3 a$ & $3 \mathrm{~b}$ & Untypable & Total & $\%$ age \\
\hline Shaving by barber & 6 & 1 & 4 & 2 & 36 & 3 & 51 & 103 & 27.46 \\
\hline Dental procedures & 0 & 1 & 4 & 0 & 8 & 5 & 4 & 22 & 5.86 \\
\hline Blood transfusion & 0 & 1 & 0 & 0 & 1 & 0 & 1 & 3 & 0.8 \\
\hline Surgery with unsterilized According $d$ materials & 0 & 1 & 1 & 1 & 0 & 1 & 8 & 12 & 3.2 \\
\hline Homosexuality & 1 & 2 & 1 & 1 & 8 & & 16 & 29 & 7.73 \\
\hline Heterosexuality & 3 & 3 & 2 & & 7 & 2 & 29 & 46 & 12.26 \\
\hline Traffic accident or puncture with other objects & 5 & 4 & 4 & 0 & 15 & 7 & 9 & 44 & 11.73 \\
\hline Intravenous drugs users & 3 & 1 & 4 & 3 & 26 & 14 & 28 & 79 & 21.06 \\
\hline Household contact in spouse & 1 & 1 & 1 & 0 & 5 & 3 & 10 & 21 & 5.6 \\
\hline Use of unsterilized materials & 1 & 0 & 1 & 0 & 6 & 1 & 7 & 16 & 4.26 \\
\hline Total & 20 & 15 & 22 & 7 & 112 & 36 & 163 & 375 & 100 \\
\hline
\end{tabular}


et al., in $2010 .{ }^{20}$ When results were further analyzed regarding patients age $21-30$ years were more effected $(30.1 \%)$, compared with other categorized variables of age Mention table no5. These results are in contrast with previous study although our findings in agreement Ali et al., 2009 in which frequency of HCV infection was higher in age group 13 to 50 and similar with Shah et al. 2010. ${ }^{21,22}$ The reason could be prognosis of HCV and awareness of health department of the region to aware them. Current study observed that untypable genotypes was the most predominant (43.5\%), followed by 3a (29.6\%) 3 b (9.6\%), 2a (5.93\%), 1a (5.3\%), $1 \mathrm{~b}(4.0 \%)$, and $2 \mathrm{~b}(1.9 \%)$ genotype in district Buner population (table.No2) as noticed in the available literature when compiled showed that HCV genotype 3a (58.16\%) was predominant in Pakistan, followed by $3 \mathrm{~b}(9.05 \%), 2 \mathrm{a}(6.70 \%), 1 \mathrm{a}(6.22 \%)$, and $1 \mathrm{~b}$ (2.39\%), the findings of the study disagreed to our findings. The reason could be routes of transmission associated with high frequency untypable genotypes.

Furthermore, another study has similar findings in comparison with our results, reported highest frequency of untypable genotypes (7.17\%), followed by $1 \mathrm{a}$ (3.84\%), $3 \mathrm{~b}$ (1.04\%), mixed genotypes constitutes only $0.67 \%$ of total infections. Genotype $2 \mathrm{a}, 2 \mathrm{~b}, 3 \mathrm{c}$, and 4 were found to be rare. ${ }^{23}$ Similar results were reported by Afzal et al. in $2014^{34}$

According to previous studies, the prevalence of HCV in district Buner was $6.45 \%$ and $2.26 \%$ respectively, ${ }^{24,25}$ which indicates less frequency as compared our findings $(34.1 \%)$ with highest frequency till date. The possible reason for this increase could be lack of knowledge and unhygienic conditions such as unsafe blood transfusion, shaving in barber shops, reuse of contaminated syringes, hemodialysis, dental procedures, contaminated surgical instruments, and blood products. ${ }^{26}$ In current research, prevalence of HCV infection was observed in both males and females. The highest frequency was found in females (51.93\%) as compared to males $(48.06 \%)$. Our findings are regarding gender analysis are in contrast with other studies. ${ }^{27}$ There are certain risk factors associated with HCV transmission however, various studies revealed that usage of excessive injections, contaminated needles, unhygienic practices in dental surgeries and unsafe blood transfusion could be the main cause of HCV transmission. Some studies also reported that sexual exposure and shaving in barber shops can also be a reason for HCV transmission in Pakistan. ${ }^{28-31}$ Our finding revealed that barber shaving to be a main cause of HCV transmission followed by Intravenous drugs. Users (IVDU). Our findings are in agreement with studies reported previously in other countries where they argued that unsafe injection, barber shaving and blood transfusion as the major routes of transmission. ${ }^{32}$ Current study also revealed association between HCV genotypes and possible routes of transmission indicates barber shaving, IVDU, dental procedures, blood transfusion, heterosexuality, homosexuality and household contact with spouse could be the cause of all genotypes incidence in HCV patients. ${ }^{33}$ In the present study untypable and 3a genotypes are predominant in barber shaving, followed by IVDU. Our findings agree with previously conducted in Pakistan ${ }^{23}$. Similarly, the same results were found in the studies conducted in USA and Europe ${ }^{34 .}$

\section{Conclusion}

The current study reveals HCV untypable variants as the most frequent genotypes in the HCV patients of district Buner KP, Pakistan, with most patients in the age group 21-30 years. HCV various isolates were associated with different routes of transmission. The predominant factors of HCV included shaving in barber shops and intra-venous drugs use. These findings may suggest anti-HCV therapy and monitoring HCV infections.

\section{Ethical approval}

The ethical approval was taken from the ethical committee at the department of Biotechnology and Genetic Engineering Hazara University Mansehra and Medical Superintendent District headquarter hospital
Buner. The informed consent was signed by the patients to Participate in the current research.

\section{Conflict of interest}

No conflict of interest.

\section{Acknowledgment}

We are very grateful to all the participant of the study and DHO district Buner for the assistance in data and samples collection. All authors are highly obliged to Dr. Muhammad Tayyab Assistant Professor in Department of Biotechnology Agriculture University Peshawar, Pakistan for their helpful discussions and proofreading.

\section{References}

1 Strader DB, Wright T, Thomas DL, Seeff LB. Diagnosis, management, and treatment of hepatitis C. Hepatology. 2004;39(4):1147-1171.

2 Taherkhani R, Farshadpour F. Global elimination of hepatitis C virus infection: progresses and the remaining challenges. World J Hepatol. 2017;9(33):1239.

3 Mostafa A, Shimakawa Y, Medhat A, et al. Excess mortality rate associated with hepatitis C virus infection: a community-based cohort study in rural Egypt. J Hepatol. 2016;64(6):1240-1246.

4 World Health Organization. Global Hepatitis Report 2017. World Health Organization; 2017.

5 Tempalski B, Pouget ER, Cleland CM, et al. Trends in the population prevalence of people who inject drugs in US metropolitan areas 1992-2007. PloS One. 2013;8(6), e64789.

6 Nagata H, Nakagawa M, Asahina Y, et al. Effect of interferon-based and-free therapy on early occurrence and recurrence of hepatocellular carcinoma in chronic hepatitis C. J Hepatol. 2017;67(5):933-939.

7 Müller CR. Novel Approaches to the Treatment of High-Grade Sarcoma. 2011.

8 Bukh J, Miller RH, Purcell RH. Genetic heterogeneity of hepatitis C virus: quasispecies and genotypes. In: Seminars in Liver Disease. 15. (C) 1995 by Thieme Medical Publishers, Inc.; 1995:41-63, 01.

9 Anwar Faheem, et al, Anwar, F., Tayyab, M., Salman, M., Abdullah, Din, M., Khan, J., \& Haq, I.. Dengue outbreak 2018 in district Shangla KPK; clinical features and laboratory markers of dengue virus infection. Future Virol. 2020;15(10):693-699, 2020.

10 Akhtar N, Ilyas M, Muhammad K, Shams S, Saeed K, Asadullah A. Prevalence of Hepatitis C virus infections among the general population of Buner, Khyber Pakhtunkhwa, Pakistan. Biomedical Research and Therapy. 2016;3(12):1003-1017.

11 Qureshi H, Bile KM, Jooma R, Alam SE, Afrid HUR. Prevalence of hepatitis B and C viral infections in Pakistan: findings of a national survey appealing for effective prevention and control measures. EMHJ-Eastern Mediterranean Health Journal. 2010; 16(Supp):15-23, 2010.

12 Akhtar N, Ilyas M, Muhammad K, Shams S, Saeed K, Asadullah A. Prevalence of Hepatitis C virus infections among the general population of Buner, Khyber Pakhtunkhwa, Pakistan. Biomedical Research and Therapy. 2016;3(12):1003-1017.

13 Idrees M. Development of an improved genotyping assay for the detection of hepatitis C virus genotypes and subtypes in Pakistan. $J$ Virol Methods. 2008;150(1-2): $50-56$.

14 Asrani SK, Devarbhavi H, Eaton J, Kamath PS. Burden of liver diseases in the world. $J$ Hepatol. 2019;70(1):151-171.

15 Butt AK, Khan AA, Khan SY, Ijaz S. Dentistry as a possible route of hepatitis C transmission in Pakistan. Int Dent J. 2003;53(3):141-144.

16 Mujeeb SA, Pearce MS. Temporal trends in hepatitis B and C infection in family blood donors from interior Sindh, Pakistan. BMC Infect Dis. 2008;8(1):1-6.

17 Mohd Hanafiah K, Groeger J, Flaxman AD, Wiersma ST. Global epidemiology of hepatitis C virus infection: new estimates of age-specific antibody to HCV seroprevalence. Hepatology. 2013;57(4):1333-1342.

18 Lam BP, Jeffers T, Younoszai Z, Fazel Y, Younossi ZM. The changing landscape of hepatitis C virus therapy: focus on interferon-free treatment. Therapeutic advances in gastroenterology. 2015;8(5):298-312.

19 Ahmad W, Ijaz B, Javed FT, et al. HCV genotype distribution and possible transmission risks in Lahore, Pakistan. World J Gastroenterol: WJG. 2010;16(34): 4321.

20 Ahmad W, Ijaz B, Javed FT, et al. HCV genotype distribution and possible transmission risks in Lahore, Pakistan. World J Gastroenterol: WJG. 2010;16(34): 4321.

21 Ali M, Kanwal L, Tassaduqe K, Iqbal R. Prevalence of hepatitis C virus (HCV) in relation to its promotive factors among human urban population of multan, Pakistan. Eur J Gen Med. 2009;6(2).

22 Ahmad W, Ijaz B, Javed FT, et al. HCV genotype distribution and possible transmission risks in Lahore, Pakistan. World J Gastroenterol: WJG. 2010;16(34) 4321.

23 Haqqi A, Munir R, Khalid M, et al. Prevalence of hepatitis C virus genotypes in Pakistan: current scenario and review of literature. Viral Immunol. 2019;32(9): $402-413$. 
24 Muhammad N, Jan MA. Frequency of hepatitis" C" in buner, NWFP. Journal of the College of Physicians and Surgeons-pakistan: JCPSP. 2005;15(1):11-14.

25 Anwar F, Khan M, Salman M, et al. Seroprevalence of hepatitis B virus in human population of district Buner Khyber Pakhtunkhwa Pakistan. Clinical Epidemiology and Global Health. 2021;10:100688.

26 Ghani MU, Haque A, Qasim M, et al. Involvement of vascular endothelial growth factor (VEGF) gene polymorphism in hepatocellular carcinoma of HCV patients from local population. Pure and Applied Biology (PAB). 2017;6(2):725-732.

27 Ali A, Nisar M, Ahmad H, Saif N, Idrees M, Bajwa MA. Determination of HCV genotypes and viral loads in chronic HCV infected patients of Hazara Pakistan. Virol J. 2011;8(1):1-6.

28 Idrees M. Development of an improved genotyping assay for the detection of hepatitis C virus genotypes and subtypes in Pakistan. J Virol Methods. 2008;150(1-2): $50-56$.
29 Raja NS, Janjua KA. Epidemiology of hepatitis C virus infection in Pakistan. J Microbiol Immunol Infect. 2008;41(1):4-8.

30 Hamid S, Umar M, Alam A, Siddiqui A, Qureshi H, Butt J. PSG consensus statement on management of hepatitis C virus infection-2003. JPMA. J Pakistan Med Assoc. 2004;54(3):146-150.

31 Ali SA, Donahue RM, Qureshi H, Vermund SH. Hepatitis B and hepatitis C in Pakistan: prevalence and risk factors. Int J Infect Dis. 2009;13(1):9-19.

32 Alter MJ. Epidemiology of hepatitis C virus infection. World J Gastroenterol: WJG. 2007;13(17):2436

33 Khan AJ, Luby SP, Fikree F, et al. Unsafe injections and the transmission of hepatitis B and C in a periurban community in Pakistan. Bull World Health Organ. 2000;78: 956-963.

34 Afzal MS, Khan MY, Ammar M, Anjum S. Diagnostically untypable hepatitis C virus variants: it is time to resolve the problem. World J Gastroenterol: WJG. 2014;20(46): 17690. 